упорядоченное удовлетворение образовательных потребностей студентов, ориентированный на личностное развитие и эффективное поэтапное формирование профессиональной компетентности, структурными компонентами которого являются образовательные нормативы, образовательные потребности, личностные возможности, влияние эдвайзеров и окружающей среды, корректирующие и предупреждающие действия, информационные потоки [4].

Образовательная траектория отражается в индивидуальных учебных планах, формируемых на каждый учебный год обучающимся самостоятельно с помощью эдвайзера на основании типового учебного плана и каталога элективных дисциплин. Индивидуальный учебный план определяет образовательную траекторию каждого обучающегося отдельно. Обучающиеся при формировании с одной стороны свободны в выборе дисциплин, с другой стороны их выбор ограничен системой пререквизитов и постреквизитов.

Пререквизиты - это перечень дисциплин, содержащих знания, умения и навыки, необходимые для освоения изучаемой дисциплины. Поэтому свобода выбора при формировании образовательной траектории имеет свои ограничения. Некорректный выбор дисциплин, несоответствующих типовому учебному плану, может затруднить формирование образовательной траектории на старших курсах.

\section{ВЫВОДЫ.}

При формировании образовательной траектории обучающиеся должны:
- ознакомиться с правилами организации учебного процесса по кредитной технологии обучения;

- изучить типовой учебный план специальности;

- определить с учетом пререквизитов возможность выбора учебных дисциплин;

- из дисциплин, доступных для выбора, сформировать индивидуальный план на текущий академический период;

- согласовать с эдвайзером выбранные дисциплины;

- соблюдать установленные сроки регистрации на учебные дисциплины и внесения изменений в индивидуальном учебном плане (ИУП).

\section{СПИСОК ЛИТЕРАТУРЫ}

1. Бережная И. А. Оценка знаний как элемент стратегии среднего профессионального образования // Специалист, 1997, № 2, с. 9.

2. Торкал Алфтан. Воздействие технологических изменений на характер и организацию подготовки работников // Человек и труд, 1993, № 2, с. 106.

3. Калацкий Э. Проблемы совершенствования системы непрерывного образования технических кадров // Мастерство, 1995, № 3, с. 30.

4.Рахымбеков А.Ж. - Методика профессионального обучения , как научная область педагогических знаний, Материалы международной конференции в ТГПУ «Профессиональное образование: проблемы и достижения», ноябрь, 2014 г., Томск.

УДК 378

ВЗАИМОДЕЙСТВИЕ ПЕДАГОГА С РОДИТЕЛЯМИ В ОСУЩЕСТВЛЕНИИ ЭСТЕТИЧЕСКОГО ВОСПИТАНИЯ ОБУЧАЮЩИХСЯ

DOI: 10.31618/ESU.2413-9335.2021.1.87.1402

Шевцова Маргарита Михайловна,

канд. пед. наук, старший преподаватель

кафедры педагогики, психологии и физической культуры

Федеральное государственное бюджетное образовательное учреждение «Кемеровский государственный институт культуры»

\title{
INTERACTION BETWEEN TEACHERS AND PARENTS IN AESTHETIC EDUCATION OF LEARNERS
}

\author{
Shevtsova Margarita Mihailovna, \\ PhD in pedagogy, Sr. Instructor \\ of department of Pedagogy and Psychology and Physical Education, \\ Kemerovo State University of Culture
}

\begin{abstract}
АННОТАЦИЯ
Статья посвящена роли эстетического воспитания в развитии личности ребенка дошкольного возраста. Рассматриваются некоторые аспекты решения проблемы эстетического воспитания обучающихся при помощи взаимодействия педагогов с родителями.

\section{ABSTRACT}

The article focuses on the role of aesthetic education in preschoolers' individual development. It examines some aspects of dealing with aesthetic education of learners through interaction between teachers and parents.

Ключевые слова: эстетическое воспитание, дошкольный возраст, взаимодействие.

Keywords: aesthetic education, preschool age, interaction.
\end{abstract}


Актуальность проблемы эстетического воспитания обучающихся в современных условиях обусловлена сегодня следующими позициями: вопервых, оно выступает важной составляющей гармоничного развития личности ребенка; вовторых, влияет на формирование полноценного восприятия ребенком окружающей его действительности - основу познания мира; втретьих, оно тесно связано со всеми сторонами развития ребенка; в-четвертых, усиливает воспитательный эффект других сторон воспитания посредством формирования эстетических чувств, эстетической отзывчивости, начальных этических понятий и оценок обучающихся.

Ускорение ритма жизни и темпа работы, повышение психического напряжения ввиду обилия и быстрой смены впечатлений создают повышенное давление на адаптационные системы организма человека. В этих условиях необходимо наличие здорового и полноценного, ориентированного на потребность человека в красоте и гармонии искусства, а также необходима учитывающая современные реалии теория и адекватно действующая на ее основе, отслеживающая все компоненты процесса, программа эстетического воспитания. Мы не ставим своей целью разработку такой программы в рамках какого-либо конкретного отдельного региона или города, но считаем, что тема нашего исследования является своеобразным вкладом в разработку программы или плана мероприятий конкретного образовательного учреждения.

Для того, чтобы взрослый человек стал духовно богатым, надо в свое время обращать особое внимание на эстетическое воспитание детей и, прежде всего, конечно дошкольного возраста. Эстетическое развитие личности начинается уже в раннем детстве, поэтому так важно понимание того, каким именно образом в этом возрасте осуществляется формирование отношения ребенка к миру, которые постепенно превращаются в свойства личности. Так считали и до сих пор считают многие педагоги, искусствоведы, ученые и практики.

Например, известный скульптор Конёнков писал: «Я никогда не вступил бы на путь искусства, если бы когда-то не полюбил музыку. И продолжал - впечатления детства во многом определяют будущее каждого человека. Эта та чаша, из которой мы пьём самый благодатный и живительный напиток. Впечатления детства, так же как и годы учения, - фундамент сознательной жизни и память об этих чистых и светлых днях, - как кладовая, в которой хранится всё незабываемое».

В свою очередь, В. А. Сухомлинский отмечал, что ребёнок по своей природе - пытливый исследователь, открыватель мира. Итак, пусть перед ним открывается чудесный мир в живых красках, ярких и трепетных звуках, в сказке, в игре, в собственном творчестве, в красоте, воодушевляющей сердце, стремлении делать добро людям» $[4$, с. $35-36]$
А. С. Макаренко неоднократно акцентировал свое внимание на том, что дети должны быть активными участниками создания красивого в жизни, потому что, изменяя действительность «по законам красоты», человек сам преображается.

Огромный вклад в развитие идей эстетического воспитания внесли и такие ученые, как Н. А. Ветлугина, Л. С. Выготский, А. Г. Гогоберидзе, Т. С. Комарова и др.

Существует множество определений понятия «эстетическое воспитание», во-первых, это процесс целенаправленного воздействия; во-вторых, это формирование способности воспринимать и видеть красоту в искусстве, жизни, оценивать ее; втретьих, задача эстетического воспитания формирование эстетических вкусов, идеалов личности; в-четвертых, - это развитие способности к самостоятельному творчеству и созданию прекрасному.

Б. Т. Лихачёв в своей книге «Теория эстетического воспитания школьников» опирается на определёние, данное когда-то К. Марксом: «Эстетическое воспитание - целенаправленный процесс формирования творчески активной личности ребёнка, способного воспринимать и оценивать прекрасное, трагическое, комическое, безобразное в жизни и искусстве жить и творить по законам красоты» [2, с. 176]. Ведь для человечества недостаточно иметь только научные знания, но и необходимо обладать красотой внутреннего мира.

Эстетическое отношение к миру - это, конечно, не только созерцание красоты, прежде всего, это стремление к творчеству по законам красоты.

Цель эстетического воспитания - выявление природных задатков и дарований человека и формирование на их основе способностей к творческому преобразованию мира по законам красоты. Воспитание красотой и посредством красоты формирует не только эстетикоценностную ориентацию личности, но и развивает способность к творчеству, к созданию эстетических ценностей в разных сферах: в трудовой деятельности, в быту, в поступках и поведении и, конечно, в искусстве. Эстетическая культура характеризует эмоциональную и интеллектуальную жизнь человека, исходя из императивов красоты, и проявляется в системе как социальных, так и индивидуальных ценностей.

Отметим, что эстетическое воспитание детей является первостепенной задачей не только для государственной образовательной системы, но и первостепенной задачей для родителей, которые хотят вырастить из своего ребёнка полноценную личность.

В настоящее время в Федеральном государственном образовательном стандарте дошкольного образования (здесь и далее - ФГОС ДО) среди пяти образовательных областей одной из центральных является область «художественноэстетическое развитие». Данная область «предполагает развитие предпосылок ценностносмыслового восприятия и понимания произведений 
искусства (словесного, музыкального, изобразительного), мира природы; становление эстетического отношения к окружающему миру; формирование элементарных представлений о видах искусства; восприятие музыки, художественной литературы, фольклора; стимулирование сопереживания персонажам художественных произведений; реализацию самостоятельной творческой деятельности детей (изобразительной, конструктивно-модельной, музыкальной и др.)» [3]. Несмотря на обозначенные установки и необходимость реализации обозначенных в данной области предпосылок, проблема эстетического воспитания обучающихся дошкольного возраста остается актуальной и в сегодняшних социально-политических, социокультурных условиях. Решить данную проблему усилиями только одних педагогов без максимально активного родительского участия просто не возможно. В связи с этим, мы предлагаем обратить внимание на организацию целенаправленного взаимодействия педагогов с родителями в осуществлении эстетического воспитания дошкольников.

В связи с этим, целью нашей исследовательской работь явилось изучение содержания и разработка плана мероприятий по взаимодействию педагогов с родителями в осуществлении эстетического воспитания обучающихся дошкольного возраста в системе дополнительного образования.

Базой

муниципальное бюджетное учреждение дополнительного образования АнжероСудженского городского округа «Оздоровительнообразовательный центр «Олимп» (здесь и далее по тексту - МБУ ДО «ООЦ «Олимп»). Администрация учреждения проявила заинтересованность и желание принять участие в данном исследовании.

Всего в исследовании приняли участие 50 родителей обучающихся дошкольного возраста, занимающихся в творческом объединении художественно-эстетической направленности, в частности хореографией в МБУ ДО «ООЦ «Олимп».

Мы не случайно выбрали творческое танцевальное объединение, так как, по мнению, Г. А. Дильдебаевой, «феномен танца, относящийся к невербальной знаковой системе и связанный с эмоциональной, чувственной стороной жизни ребенка, является уникальным и ничем не заменимым средством воспитания» [1, с. 314].

Ребенок, владеющий танцевальной осанкой, восхищает окружающих. Дисциплинированность, трудолюбие и терпение, которые требуется демонстрировать на каждом занятии, становятся свойствами характера ребенка, необходимыми ему не только в хореографическом классе, но и в быту. Аккуратность в хореографическом исполнительстве, опрятность формы в хореографическом классе переносится и на внешний вид детей в повседневной жизни. Они выделяются не только своей осанкой, но и прической, чистотой и элегантностью ношения самой обычной повседневной одежды. Воспитание этикета, поведения, межличностных отношений является одной из сторон на занятиях по хореографии. Хореографическое искусство у ребенка является дополнением и продолжением его реальной жизни, обогащая ее. Совершенно очевидно, что каждый педагог посредством эстетического воспитания готовит детей к преобразовательной деятельности. Педагогхореограф конечно способен сформировать, развить и укрепить у детей потребность в общении с искусством, понимание его языка, любовь и хороший вкус к нему. Но без помощи родителей, без проявления их непосредственного участия в творческой жизни своего ребенка достигать эффективного результата намного сложнее.

Для решения проблемь по эффективному осуществлению эстетического воспитания обучающихся мы разработали программу исследования, включающую в себя три этапа.

На первом этапе была проведена первичная педагогическая диагностика, посредством метода опроса - анкетирования. Цель диагностики: выявление отношения родителей к необходимости осуществления эстетического воспитания обучающихся, определение ожиданий и предпочтений родителей в этом направлении и установление желания родителей участвовать в совместных с учреждением мероприятиях. Отметим, что анкета, состояла из 17 вопросов, объединенные в так называемые условные блоки, которые направлены на выявление ожиданий как общих, так и частных предпочтений родителей в вопросах эстетического воспитания. По итогам первого этапа мы сформулировали основные задачи по организации дальнейшего взаимодействия педагогов с родителями.

1. Установить партнерские отношения с семьей ребенка.

2. Объединить усилия для эстетического воспитания обучающихся.

3. Создать атмосферу взаимопонимания, общности интересов, эмоциональной взаимоподдержки.

4. Активизировать и обогатить воспитательные умения родителей в организации эстетического воспитания обучающихся.

На втором этапе по результатам, полученным в ходе диагностики, родителям были предложено участие в небольших творческих заданиях - по итогам которых родители писали мини-сочинения на тему: «Я и мой ребенок в процессе эстетического воспитания» по принципу метода незаконченных предложений. В сочинении давалось пять утверждений с начатой формулировкой, которую нужно было продолжить самим родителям, опираясь на итог совместной работы со своим ребенком в ходе выполненного ими творческого задания. Помимо творческих заданий, было предложено использовать игровые упражнения, направленные на взаимодействие, как педагогов с родителями, так и родителей со своими детьми. 
Приведем ряд примеров таких игровых упражнений: «Я видел сегодня» - суть упражнения заключается в том, что участник в руках которого оказывается микрофон - взрослый или ребенок, произносит фразу, начинающуюся словами «Я видел(а) сегодня...», завершая ее окончание своим собственным предложением - «Я видел сегодня распускающиеся листочки», после чего передает микрофон любому другому человеку, находящемуся в аудитории. Другое игровое упражнение «Я наблюдательныци» - состоит в том, что ведущий предлагает всем участникам закрыть глаза. При этом он произносит некоторые утверждения, соглашаясь с которыми участники поднимают руку вверх, если нет - не поднимают. После каждого ответа, участники открывают глаза, и проверяют его верность. Примеры некоторых утверждений: «На мне сегодня надеты бусы», «У нас сегодня есть человек в кроссовках», «Среди нас есть блондины» и т. д.

На третьем этапе - происходило заполнение карт «Определения характера взаимодействия родителя с ребенком», причем карты заполняли как сами родители, так и эксперты, выбранные из числа педагогов, наблюдавшие за совместной работой родителей с их детьми.

Таким образом, в ходе проведенного исследования мы получили подтверждающие результаты того, что большинство родителей заинтересованы в развитии рассматриваемой нами темы, а также готовы принимать участие в совместных мероприятиях, проводимых «ООЦ «Олимп» по направлениям эстетического воспитания обучающихся.

Исходя из проведённого исследования, можно сделать выводы о том, что большая часть родителей обучающихся, занимающихся в МБУ ДО «ООЦ «Олимп», считают, что эстетическое воспитание ребёнка должно быть обязательным, начинать которое необходимо как можно раньше. При этом родители стараются, чтобы эстетическое воспитание дети получали не только на занятиях танцами, музыкой, изобразительной деятельностью, но и дома. Соответственно сами родители готовы с помощью педагогов, а в дальнейшем и самостоятельно «прививать» детям вкус и стремление к красоте, правильно выстраивая взаимодействие. При этом как показали результаты анкетирования, большая часть детей уже на данном этапе задаёт вопросы родителям об искусстве, дети любят заниматься разными видами творческой деятельности: музыкой, хореографией, изобразительной деятельностью. Большая часть детей танцует в любое свободное время, и с радостью демонстрирует новые танцевальные движения, освоенные ими на занятиях. Родители хотели бы, чтобы занятия хореографией проводились чаще, так как это благоприятно влияет на их детей.

Результаты данного исследования могут быть использованы как в области дополнительного образования, так и в области дошкольного и начального общего образования для решения вопросов по осуществлению эстетического воспитания обучающихся.

\section{Список литературы}

1. Дильдебаева, Г. А. Роль народных танцев в эстетическом воспитании / Г. А. Дильдебаева // Материалы международной научно-практической конференции «Инновационные явления в современной культуре Казахстана». Алматы, 2008. - C. 311-317.

2. Лихачев, Б. Т. Теория эстетического воспитания школьников : учебное пособие по спецкурсу для студентов пед. ин-тов. М.: Просвещение, 2005. - С. 176.

3. Об утверждении Федерального государственного образовательного стандарта дошкольного образования: приказ Минобрнауки Российской Федерации от 17.10.2013 г. № 1155 // Вестник образования. - 2013. - No 24. - С. 3-32.

4. Сухомлинский, В. А. Сердце отдаю детям. Киев : Радянська школа, 1974. - 288 с. 